\title{
Retracted: 2. Das Phänomen ,Essstörung im sozial- und humanwissenschaftlichen Diskurs
}

published in: Stefanie Richter, Essstörung, 9783839404645

\section{Retraction}

We apologize that the content of this title is not available for purchase and no longer accessible. Due to an unforeseeable rights problem, we have permanently removed the content from our online platform.

Thank you for your understanding.

Wir bitten Sie zu entschuldigen, dass der Inhalt dieses Titels nicht mehr für Sie erhältlich und nicht online zugänglich ist. Aufgrund eines nicht vorhergesehenen Rechteproblems mussten wir den Inhalt leider dauerhaft von unserer Online-Plattform entfernen.

Wir bitten Sie um Ihr Verständnis. 